\title{
Analisis Penurunan Kualitas Air Ketel Guna Menunjang Performa Ketel Bantu di MV. Tangguh Sago
}

\author{
Ali Muktar S. ${ }^{1}$, Asman $\mathrm{Ala}^{2}$, Reza Sepdeya ${ }^{3}$ \\ 1, 2, ${ }^{3}$ Prodi Teknika \\ Sekolah Tinggi Ilmu Pelayaran, Jakarta \\ Jl. Marunda Makmur No. 1 Cilincing, Jakarta Utara. Jakarta 14150
}

\begin{abstract}
Abstrak
Kapal Niaga digunakan sebagai salah satu alat transportasi laut yang sangat penting peranannya dalam dunia perdagangan khususnya yang menggunakan jalur laut. Beberapa masalah yang ditemukan di kapal adalah terjadinya korosi sehingga terbentuk lubang dan peretakan pada perpipaan ketel uap, kemudian terbentuknya pengumpulan zat dalam air umpan boiler. Tujuan dilakukan penelitian ini adalah untuk mengetahui penyebab dan pemecahan masalah terjadinya korosi kemudian untuk mengetahui penyebab terbentuknya deposit dalam air umpan boiler. Metode yang digunakan adalah deskriptif kualitatif. Dari hasil penelitian diperoleh kesimpulan bahwa penyebab terjadinya korosi sehingga terjadi pembentukan lubang dan peretakan pipa pada air ketel adalah rendahnya kandungan $\mathrm{pH}$ di air ketel dan kurangnya penambahan chemical treatment. Penyebab terjadinya deposit pada air umpan ketel uap adalah tingginya kadar P. Alkalinity.
\end{abstract}

Kata Kunci: kualitas, air ketel, analisis

Copyright (C) 2020, Prosiding Seminar Pelayaran dan Riset Terapan

Permalink/DOI : https://doi.org/10.36101/pcsa.v2i1.136

\section{PENDAHULAN}

Kita ketahui bahwa secara geografis bumi merupakan sebuah wilayah yang sebagian besar daerahnya adalah perairan, sehingga transportasi laut merupakan transportasi yang paling tepat sebagai sarana penghubung antar pulau. Transportasi merupakan aset yang sangat penting dan berharga. Transportasi harus dikelola dengan baik dan benar, khususnya yang berhubungan dengan transportasi laut guna menjalankan roda perekonomian.

Dalam pelaksanaanya, pengoperasian transportasi laut tergantung dari pengelolaan Sumber Daya Manusia (SDM), kesejahteraan dan kenyamanan awak kapal, sehingga diharapkan awak kapal dapat bekerja secara maksimal.

Pada dasarnya, kapal laut digunakan sebagai salah satu alat transportasi laut yang sangat penting peranannya dalam dunia perdagangan khususnya yang menggunakan jalur laut menuntut performa mesin induk yang efisien dan permesinan bantu yang tangguh dalam beroperasi.

Untuk menunjang kelancaran pelayanan dan pelayaran dibutuhkan pesawat-pesawat bantu di antaranya adalah ketel uap bantu di mana berfungsi sebagai penghasil uap panas yang akan digunakan untuk memanaskan muatan, memompa keluar muatan, memanaskan bahan bakar, sebagai pengontrol suhu udara bila kita berlayar di daerah dingin dan di gunakan untuk keperluan lainnya. Ketel uap dituntut untuk selalu dapat menghasilkan uap panas yang mencukupi sesuai kebutuhan di atas kapal.

Tersedianya uap panas merupakan hal yang mutlak bagi kelancaran operasional permesinan yang membutuhkan uap panas. Namun kenyataanya pada saat tim peneliti observasi di atas kapal sering terjadi permasalahan pada ketel uap yang dimaksud, seperti terjadinya korosi, terbentuknya deposit, terbentuknya kerak pada sistem, terciumnya bau yang tidak normal, dan timbulnya gelembung pada permukaan air boiler sehingga performa dari ketel bantu menurun.

Permasalah-permasalahan yang ada disebabkan karena turunnya kualitas air ketel. Peran kualitas air sangatlah vital, oleh karena itu kualitas air harus dijaga secara optimal demi menunjang performa ketel bantu dalam menghasilkan uap. Kualitas air ketel sesuai buku instruksi manual, $\mathrm{pH}$ ketel uap normal berkisar 10.8-11.3, $\mathrm{pH}$ air umpan adalah 8.3-9.0, dan maksimal P. Alkalinity adalah 500. Di latar belakangi permasalahan yang penulis alami dan pentingnya kualitas air ketel yang benar guna menunjang ketel uap agar selalu dalam keadaan yang selalu siap beroperasi. Oleh karena itu peneliti tertarik untuk mengkaji tentang analisis penurunan kualitas air ketel guna menunjang performa ketel bantu di MV. Tangguh Sago. 
Berdasarkan hal tersebut peneliti menguraikan identifikasi masalah, yaitu:

1. Terjadinya korosi (pembentukan lubang dan peretakan baja atau pipa).

2. Terbentuknya deposit (pengendapan zat) dalam air umpan boiler.

3. Terbentuknya kerak pada sistem pipa di boiler.

4. Terciumnya bau yang tidak normal pada air boiler

5. Timbulnya gelembung pada permukaan air boiler

Berdasarkan uraian yang telah disampaikan dalam latar belakang, peneliti merumuskan permasalahan sebagai berikut:

1. Apa penyebab terjadinya korosi sehingga terbentuk lubang dan peretakan pada perpipaan ketel uap?

2. Bagaimana terbentuknya deposit (pengumpulan zat) dalam air umpan boiler?

Kemudian tujuan dilaksanakannya penelitian ini yaitu:

a. Untuk mengetahui penyebab dan pemecahan masalah dari terjadinya korosi (pembentukan lubang dan peretakan baja atau pipa).

b. Untuk mengetahui penyebab terbentuknya deposit dalam air umpan boiler

\section{METODE}

Metode Pendekatan yang digunakan dalam penelitian ini adalah metode pendekatan deskriptif kualitatif. Dalam memperoleh data peneliti menggunakan teknik pengumpulan data berupa observasi. Observasi adalah pengumpulan data berupa informasi berdasarkan pengamatan langsung oleh peneliti di MV. Tangguh Sago.

\section{HASIL DAN PEMBAHASAN}

Pada kapal MV. TANGGUH SAGO, ketel uap bantu yang digunakan merupakan ketel uap bantu tipe pipa air yaitu Vertical Oil-Fired Water Tube Boiler buatan Kangrim Industries Co., LTD.

Bila mesin utama tidak beroperasi, ketel uap bantu akan dioperasikan untuk menjaga temperatur bahan bakar di atas kapal. Oleh karena itu, pasokan uap sangat dibutuhkan diseluruh bagian kapal yang membutuhkan pemanasan yang berasal dari ketel uap. Saat mesin utama telah menyala,bagian exhaust atau economizer mulai beroperasi. Bila beban pada mesin utama rendah, baik pada bagian economizer maupun bagian pembakaran minyak akan beroperasi untuk memasok uap yang dibutuhkan ke seleuruh bagian kapal. Ketika perhitungan revolusi mesin utama telah meniningkat, jumlah uap yang dihasilkan oleh bagian exhaust atau economizer juga meningkat, sementara bagian pembakaran minyak telah berhenti beroperasi. Dengan demikian, bagain exhaust atau economizer saja yang bekerja untuk memasok uap yang dibutuhkan keseluruh bagian kapal yang membutuhkan.

Pada saat kapal berlayar di laut, bagian exhaust atau economizer saja yang beroperasi. Bila jumlah uap yang dibutuhkan lebih besar dari jumlah uap yang direncanakan atau dihasilkan oleh exhaust atau economizer, dengan demikian ketel bantu akan beroperasi untuk memasok uap yang dibutuhkan.

Sistem kerja dari ketel uap tipe pipa air ini yaitu dimana feed-water tank atau cascade tank menampung air yang akan didistribusikan ke dalam ketel uap. Pertama, air didalam feed-water atau cascade tank akan mengalir melalui feed water pump, dimana nantinya akan masuk kedalam drum ketel uap, kemudian air di dalam pipa dipanaskan oleh api dari hasil pembakaran.

Air di dalam pipa tersebut nantinya akan terkondensasi dan membentuk uap bertekanan tinggi. Pada keseluruhan sistem di dalam ketel uap ini terutama pada bagian air umpan, tekanan uap diatur menggunakan kran dan di pantau dengan alat pemantau tekanan (pressure gauge) dan alat pemantau level air (level gauge). Air yang disuplai ke ketel uap untuk dirubah menjadi uap bertekanan disebut air umpan. Dua sumber air umpan yaitu kondensat atau uap yang mengembun yang kembali dari proses dan distillate water yang harus diisi dari luar sistem ketel uap. Untuk mendapatkan efisiensi boiler yang lebih tinggi, digunakan economizer untuk memanaskan awal air umpan menggunakan limbah panas pada gas buang.

Pada dasaranya, ketel uap bantu tipe pipa air ini memanfaatkan exhaust gas yang berasal dari main engine yang selanjutnya akan masuk ke dalam ruang pembakaran (furnance). Di dalam ruang pembakaran ketel uap, air dipanaskan lagi dengan burner sebagai pemanas lanjutnya. Uap bertekanan akan disalurkan kesemua bagian yang memerlukan uap. Di kapal MV. TANGGUH SAGO dengan tipe vertical oil-fired water tube boiler MB0406BS11 hanya memiliki batas maksimum design pressure $1.00 \mathrm{MPa}$ dan normalnya hanya 0.9 Mpa. Ketel uap bantu yang berada pada kapal memiliki tingkat evaporasinya yaitu sebesar $15000 \mathrm{~kg} / \mathrm{h}$.

Pada saat peneliti melakukan pengamatan di MV. TANGGUH SAGO terjadi permasalahan pada ketel bantu sebagai berikut ini.

Pertama, terjadinya korosi pada sistem perpipaan ketel uap yang menyebabkan lubang di pipa keluaran pompa sirkulasi nomor satu yang berdiameter 2-2.5 $\mathrm{cm}$ sehingga air mengalir keluar secara berlebihan. Hal ini terjadi saat kapal sedang 
berlayar dari Pelabuhan Tangguh menuju Pelabuhan Incheon pada tanggal 2 Januari 2016. Untuk penanggulangan pertama yang dilakukan untuk kebocoran air ketel pada lubang di pipa adalah masinis yang bertanggung jawab terhadap ketel uap segera mengganti pompa sirkulasi dengan yang nomor dua dan melakukan isolasi terhadap pompa nomor satu dengan menutup katup inlet dan outlet dari pompa. Permasalah lubang pada pipa karena korosi ini yang menjadi salah satu pusat perhatian penulis untuk menganalisis apa sebenarnya yang menyebabkan hal ini terjadi.

Kedua, terbentunya deposit pada tanki air umpan ketel uap, hal ini ditemukan pada hari yang sama terjadi kebocoran air pada sistem ketel uap karena jumlah air yang ada di sistem pasti berkurang, alarm di IAS (Integrated Automation System) yang berada di Engine Control Room juga menunjukan cascade tank dalam kondisi low level. ABK mesin ditugaskan oleh 3rd Enginner melakukan pengisian ulang pada cascade tank, pada saat itu ditemukan bahwa terdapat endapan di cascade tank tersebut. Adanya endapan di dalam air ketel merupakan salah satu indikasi bahwa kualitas air ketel dalam kondisi yang tidak baik, jika dibiarkan begitu saja akan menyebabkan masalah bagi sistem ketel uap tersebut. Karena hal tersebut penulis melakukan pengecekan laporan hasil water analysis sebelumnya dimana hasil laporan tersebut menunjukkan kualitas air yang baik dimana seharusnya tidak ada endapan yang berada di cascade tank.

Berdasarkan data yang diperoleh, peneliti menjabarkan analisis data dari masalah yang terjadi, sebagai berikut:

Pertama, korosi pada sistem perpipaan air ketel merupakan kerusakan atau degradasi logam akibat reaksi redoks antara suatu logam dengan berbagai zat di lingkungannya yang menghasilkan senyawa-senyawa yang tidak dikehendaki, karena kandungan $\mathrm{pH}$ yang tidak stabil pada air ketel uap bantu. Korosi pada permasalahan yang dialami disebabkan oleh:

a. Rendahnya kandungan $\mathrm{pH}$ pada air ketel uap bantu

Nilai $\mathrm{pH}$ rendah merupakan salah satu kondisi yang memicu terjadinya korosi. Hal ini sangat berbahaya karena pada saat $\mathrm{pH}$ rendah, ion hidrogen akan melapisi permukaan logam sehingga menimbulkan gas yang meninggalkan permukaan logam dan dapat menyebabkan terjadinya korosi. Ion hidrogen yang terbentuk akan menembus kerak sehingga pada saat bertemu dengan permukaan pipa akan mendekarbonasi pipa tersebut.

Peristiwa korosi pada kondisi asam, yakni pada kondisi $\mathrm{pH}<7$ semakin besar, karena adanya reaksi reduksi tambahan yang berlangsung pada katode yang menyebabkan lebih banyak atom logam yang teroksidasi sehingga laju korosi pada permukaan logam semakin besar. Kondisi $\mathrm{pH}$ di dalam ketel harus benar-benar memenuhi persyaratan yang telah ditentukan, yang artinya sesuai dengan yang diinginkan menurut buku petunjuk ketel uap untuk mencegah terjadinya permasalahan yang dapat menimbulkan kondisi yang tidak sesuai ataupun kondisi yang berbahaya.

Ketika $\mathrm{pH}$ dalam kondisi tinggi, material pipa di dalam ketel uap dapat berubah menjadi sangat rapuh akibat konsentrasi basa yang meningkat. Air ketel yang telah bersifat basa tersebut dapat secara berlahan masuk ke sela-sela material pipa dan menimbulkan reaksi kimia sehingga akan menyebabkan bagian-bagian pipa seperti lekukan dan akan menjadi rapuh.

Untuk membuktikan rendahnya kandungan $\mathrm{pH}$ menjadi faktor terjadinya lubang pada pipa air ketel maka dilakukan analisis kandungan kualitas air ketel yang sesuai dengan buku instruksi manual sebagai berikut :

1) Mengambil sampel air di titik yang ditentukan yaitu pada sampling valve di samping ketel uap dan di dari dalam cascade tank.

2) Menunggu suhu sampel air mencapai 25$27^{\circ} \mathrm{C}$.

3) Menuangkan $50 \mathrm{ml}$ sampel air kedalam wadah sampel yang telah di sediakan.

4) Menuangkan 0,6 gram serbuk putih chemical ke dalam wadah sampel, kemudian aduk sampai merata.

5) Mengambil kertas lakmus untuk ukuran ketel uap $(7,5-14,0)$ dan untuk ukuran air umpan ketel uap (6,5-10,0) kemudian masukan kedalam wadah sampel tunggu sampai satu menit.

6) Setelah itu, mencocokan kertas lakmus dengan warna yang telah disediakan sesuai dengan $\mathrm{pH}$ masing-masing, indikator pada air ketel menunjukkan nilai $\mathrm{pH} 6.5$ dan air umpan ketel uap menunjukkan nilai pH 9,0.

7) Dan yang terakhir adalah mencatat hasil kualitas yang terjadi pada nilai $\mathrm{pH}$ ke $\log$ book for Boiler Water Test.

Dari hasil analisis yang dilakukan ditemukan bahwa $\mathrm{pH}$ pada air ketel dalam kondisi yang tidak seusai dengan ketentuan buku instruksi manual ketel uap dimana nilai $\mathrm{pH}$ normal untuk air ketel adalah 10,8-11,3 dan air umpan adalah 8,3-9,0. Hal ini membuktikan bahwa rendahnya kandungan $\mathrm{pH}$ menjadi salah satu faktor pemicu penyebab terjadinya korosi pada sistem perpipaan 
ketel uap.

b. Kandungan oksigen di dalam air terlalu tinggi

Pada proses pengaratan, besi $(\mathrm{Fe})$ bertindak sebagai pereduksi dan oksigen $(\mathrm{O} 2)$ yang terlarut dalam air bertindak sebagai pengoksidasi. Oksigen menjadi salah satu gas yang mudah larut di dalam air dan menjadi penyebab utama terjadinya korosi pada pipa-pipa ketel uap. Untuk menghilangkan oksigen yang terlarut di dalam air ketel diperlukannya pemanasan awal air umpan sebelum masuk ke dalam ketel uap. Penghilangan oksigen, karbon dioksida dan gas lain yang tidak dapat terembunkan dari air umpan ketel uap sangat penting bagi umur peralatan ketel uap dan juga keamanan operasi.

Untuk membuktikan kandungan oksigen di dalam air ketel maka dilakukan DEHA Test, analisa ini mengecek kandungan Diethylhydroxylamine, langkah-langkah yang dilakukan sesuai buku instruksi manual adalah sebagai berikut:

1) Menyiapan 2 buah botol sampel (botol A dan botol B) berukuran $10 \mathrm{~mL}$

2) Menuangkan $10 \mathrm{~mL}$ sampel air ketel uap terhadap masing-masing menggunakan jarum suntik.

3) Menambahkan 6 tetes DEHA test solution pada botol A dan diaduk secara merata.

4) Menambahkan 1 DEHA test tablet pada botol A, hancurkan tablet sehingga menyatu dengan air sampel, dan menunggu 10 menit sampai benar-benar merata.

5) Sambil menunggu air sampel di botol A, menambahkan juga DEHA test tablet pada botol B, menghancurkannya juga dan menunggu juga 10 menit pada sampel di botol B.

6) Setelah air sampel benar-benar larut selama 10 menit, taruh botol A di bagian kiri comparator, dan botol B di bagian kanan comparator.

7) Mencocokan warna air sampel dengan di bagian kiri dengan kepingan pembandingan yang menutupi botol B menghadap cahaya yang terang.

8) Mendapatkan hasil bahwa kepingan yang cocok adalah menunjukan bahwa kandungan oksigen yang terlarut di dalam air ketel adalah 0,04 .

Dari hasil analisis yang dilakukan tidak ditemukan bahwa kandungan oksigen di dalam air terlalu tinggi, hal ini dibuktikan dengan DEHA test. Faktor lain yang mempengaruhi kandungan oksigen karena suhu air umpan selalu di monitor untuk sesuai dengan panas ketentuan yang berlaku dimana oksigen tidak akan terkandung dalam air ketel, dan juga penambahan chemical treatment oxygen scavenger pun rutin dilakukan untuk mengikat oksigen yang terlarut di air ketel.

c. Kurangnya penambahan chemical treatment pada air ketel

Perawatan internal penambahan zat kimia ke dalam sistem ketel uap ditentukan oleh hasil dari pengetesan kandungan air yang dilakukan setiap hari. Penambahan zat kimia bertujuan untuk menjaga unsur kekerasan (hardness) air ketel, menjaga tingkat alkalinitas air ketel, menjaga kadar zat-zat terlarut pada batasannya, mengikat oksigen. menjaga kadar $\mathrm{pH}$, dan menjaga kandungan garam air ketel.

Pada saat daily water analysis dilakukan secara keliru maka penambahan zat kimia pun akan mengalami kesalahan. Dari hasil analisis yang di lakukan pada laporan sebelumnya dinyatakan bahwa kandungan air ketel dalam kondisi baik, maka tidak dilakukannya penambahan zat kimia ke dalam sistem untuk menjaga kandungan air ketel yang sesuai ketentuan. Dapat dikatakan bahwa hal ini merupakan salah satu kesalahan dalam proses perawatan air ketel karena hasil percobaan kimia yang salah berdampak pada kesalahan perawatan chemical treatment yang dilakukan pada air ketel.

d. Tidak berjalannya perawatan untuk menjaga kualitas air ketel dengan baik

Dalam menjaga kualitas air ketel di atas kapal perlu melakukannya pelaksanaan PMS (Planned Maintenance System). Perawatan sesuai dengan interval waktu yang telah ditentukan sedemikian rupa sehingga kerusakan ketel uap dan kualitas air ketel dapat dijaga. Dari hasil analisis yang dilakukan, PMS di kapal MV. Tangguh Sago dilakukan secara baik dan benar, hal ini dibuktikan dengan sebuah sistem yang menyimpan semua laporan perawatan yang dilakukan pada ketel uap. Sistem di kapal ini disebut dengan NS5, setiap masinis yang melakukan perawatan maupun perbaikan terhadap suatu permesinan diwajibkan untuk membuat sebuah laporan secara detail yang akan tersimpan secara komputerisasi untuk dilaporkan lebih lanjut kepada shore-based management yang ada di kantor.

Kedua, terbentuknya deposit dalam air umpan boiler mengakibatkan menurunnya efektifitas perpindahan panas. Permasalahan ini dapat disebabkan oleh :

a. Tingginya kadar P. Alkalinity

Pada dasarnya, alkalinity merupakan butiranbutiran kecil yang terkandung di dalam air ketel, yang jika nilainya terlalu tinggi dan tidak sesuai dengan ketentuan buku manual ketel uap dapat menjadi deposit yang bias merugikan performa 
ketel uap. Berkaitan dengan ini maka penulis membuktikan ini maka dilakukan pengecekan kandungan P. Alkalinity pada air umpan ketel uap sebagai berikut :

1. Menuangkan $200 \mathrm{ml}$ sampel air umpan dalam wadah tertutup yang bersih dan kering.

2. Selanjutnya menambahkan 1 tablet $P$. Alkalinity ke dalam wadah tertutup dan goyangkan wadah tersebut sampat tablet hancur dan akan berubah warna menjadi biru.

3. Mengulangi penambahan tablet (jeda beberapa detik sampai tablet benar-benar larut), penambahan tabe berhenti sampai larutan berubah warna menjadi kuning secara permanen. Larutan berubah menjadi kuning setelah 18 tablet P. Alkalinity ditambahkan ke dalam sampel air umpan ketel uap.

4. Menghitung jumlah tablet yang telah digunakan dan lakukan penghitungan $\mathrm{P}$. Alkalinity, ppm $\mathrm{CaCO}_{3}=$ (Jumlah tablet yang digunakan x 20) -10 . Karena 18 tablet yang digunakan maka, P. Alkalinity $=$ $(18 \times 20)-10=350 \mathrm{ppm} \mathrm{CaCO}_{3}$.

5. Setiap pegecekan dilakukan, hasil yang telah dihitung dicatat kedalam log book for Boiler Water Test.

Dari hasil analisis yang dilakukan ditemukan bahwa kadar P. Alkalinity pada tanki air umpan boiler adalah $350 \mathrm{ppm}$, dimana nilai normalnya adalah 100-300 ppm. Pada kondisi yang tidak sesuai ini, alkalinity akan menjadi endapan jika air telah dipanasi. Saat melakukan analisa air pada ketel uap bantu, kita harus benar dan akurat dalam setiap langkah yang kita uji, karena bila salah satu langkah tidak sesuai dengan instruksi buku manual, ini akan mempengaruhi nilai dari kadar alkalinitasnya.

b. Kontaminsi uap dari hasil proses pertukaran panas

Setelah air umpan masuk ke dalam ruang pembakaran, maka air ketel akan menjadi uap yang digunakan untuk pemasan maupun pengoperasian di kapal. Terdapat tiga kali proses pertukaran panas yang memungkinkan terjadinya kontaminasi, yaitu pada saat uap memanaskan MDO (Marine Disel Oil), Lubricating Oil dan pada saat uap didinginkan di dump condenser. Di cascade tank terdapat Inspection Glass yang memungkinkan kita melihat secara visual air di dalam tanki. Pada saat dilakukan pengecekan tidak ditemukannya kontaminasi MDO ataupun LO. Dari hasil analisis yang dilakukan dapat dinyatakan bahwa tidak ada kontaminasi uap dari hasil proses pertukanan panas pada system ketel

uap.

c. Terkandungnya zat-zat yang tidak dapat larut

Dalam sistem air ketel memungkinkan adanya zat yang tidak dapat larut, seperti silikat dan oksida besi. Untuk membuktikan ini dilakukan inspeksi visual pada cascade tank melalui penutup bagian atas tanki tersebut. Dari hasil analisis tidak ditemukannya zat-zat yang mengandung silikat $\left(\mathrm{CaSiO}_{3}\right)$ dalam air umpan boiler seperti pasir, debu, pecahan batu bara, bahan isolasi. Pada umunya silikat muncul karena adanya pemasangan atau proses pembangunan ketel uap. Oksida besi $\left(\mathrm{Fe}_{3} \mathrm{O}_{4}\right)$ yang biasa berwarna kemerahan juga tidak ditemukan di dalam air umpan boiler.

Berdasarkan analisa data yang telah peneliti kemukakan, maka alternatif pemecahan masalah yang sesuai yaitu :

Pertama, terjadinya korosi pada pipa air ketel disebabkan oleh:

a. $\mathrm{pH}$ yang rendah, treatment yang dilakukan:

1) Memberikan chemical treatment dengan memasang dosing pump tambahan pada pompa air umpan ketel uap. Dengan penambahan pompa ini maka supplai bahan kimia untuk perawatan air ketel akan bertambah dimana dibutuhkan untuk meningkatkan nilai $\mathrm{pH}$ yang rendah. Cara ini tidak langsung akan meningkatkan nilai $\mathrm{pH}$, dibutuhkan waktu sekurang-kurangnya 12 jam agar hasil dari penambahan bahan kimia dapat tercampur secara merata di seluruh system ketel uap.

2) Memberikan chemical treatment secara langsung ke dalam tanki cascade tank. Penambahan bahan kimia biasanya disupplai secara perlahan dari tanki larutan bahan kimia, cara ini dilakukan dengan memberikan langsung chemical treatment murni yang dimasukkan ke dalam cascade tank.

Dosis chemical treatment yang disupplai melalui kedua cara tersebut harus sesuai berdasarkan table yang dianjurkan buku intruksi manual.

Tabel 1. Analisa $p \mathrm{H}$ di dalam Ketel Uap Bantu

\begin{tabular}{|c|c|c|c|}
\hline \multicolumn{3}{|c|}{$p \mathrm{H}$ ketel uap bantu } & \multirow{2}{*}{$\begin{array}{c}\text { Standar } \\
p \mathrm{H}\end{array}$} \\
\cline { 1 - 3 }$<10,8$ & $10.8-11,3$ & $>11,3$ & \\
\hline \multicolumn{3}{|c|}{$p \mathrm{H}$ air umpan } \\
\hline$<8,3$ & $8,3-9,0$ & $>9,0$ & \\
\cline { 1 - 3 } $\begin{array}{c}\text { Meningkat } \\
\text {-kan dosis } \\
\text { sampai }\end{array}$ & Normal & $\begin{array}{c}\text { Menurun } \\
\text { kan dosis } \\
\text { sampai }\end{array}$ & \multirow{2}{*}{$10.8-11,3$} \\
$\begin{array}{c}\text { 25\% dan } \\
\text { tes }\end{array}$ & & $\begin{array}{c}25 \% \text { dan } \\
\text { tes }\end{array}$ & \\
\hline
\end{tabular}


kembali

kembali

b. Kurangnya penambahan chemical treatment pada air ketel, treatment yang dilakukan:

1) Melakukan analisa air ketel melalui percobaan kimia yang sesuai dengan buku instruksi manual dan memberikan arahan mengenai injeksi atau penambahan bahan kimia pada air ketel. Memberikatan dosis yang tepat adalah suatu tindakan pencegahan terhadap korosi yang terjadi di ketel uap. Dalam memberikan penambahan bahan kimia diperlukannya pemeriksaan (analisis) kualitas air pengisian ketel, dimana hasil yang didapat menjadi acuan untuk seberapa banyak dosis yang dapat diberikan terhadap ketel uap. Hasil analisa harus dicatat dengan baik dan benar sehingga perawatan pada air ketel dapat berjalan dengan maksimal. Dalam melakukan perawatan air ketel dengan menambahkan bahan kimia harus memperhatikan persediaan yang ada dan peralatan keamanan harus selalu di pakai dengan benar dan pada posisi yang tepat, seperti: sarung tangan, masker, kacamata dan lain-lain. Hal ini bertujuan untuk mencegah kejadian yang tidak diinginkan.

2) Mengganti interval kegiatan water analysis pada air ketel yang biasanya dilakukan setiap tiga hari sekali menjadi setiap dua hari sekali. Dengan hal ini maka akan menambah keakuratan dari hasil laporan yang dibutuhkan untuk penambahan bahan kimia yang diperlukan untuk menjaga kualitas air ketel.

Kedua, terjadinya deposit pada air umpan ketel uap disebebkan oleh satu faktor yaitu Tingginya kadar P. Alkalinity, maka dari itu alternatif pemecahan masalahnya adalah:

a. Memberikan bahan kimia ke dalam sistem yang tepat dengan memperhitungkan dosis bahan kimia dalam jumlah yang tepat.

Pemeriksaan yang rutin dijalankan setiap hari sangatlah diperlukan karena kondisi air sewaktuwaktu terus berubah. Untuk itu diperlukan pendataan serta catatan dalam pemberian perawatan kimia pada air ketel. Masinis harus membuat grafik atau skala perbandingan antara air dan pemberian bahan kimia yang ditambahkan ke dalam air untuk kadar yang tepat. Dalam hal ini bahan kimia yang digunanakan Autrotreat.

Larutan Autotreat dapat mencegah terjadinya endapaan dan korosi di dalam sistem perpipaan dari ketel uap bantu dan juga memperpanjang umur di dalam sistem air umpan yang seluruh alirannya masuk ke dalam sistem perpipaan ketel uap bantu.

b. Melakukan blowdown pada ketel uap

Dengan melakukan blowdown yang terkontrol, dapat mengurangi konsentrasi kotoran di dalam ketel dan menjaga kualitas air ketel di samping dengan melaksanakan injeksi bahan kimia yang disertai dengan percobaan kimia yang sesuai dengan prosedur di dalam buku manual. Ada dua jenis blowdown, yaitu Surface Blowdown dan Bottom Blowdown.

Surface blowdown dilakukan dari uap drum pada ketel uap ke laut. Proses in bertujuan untuk mengurangi kotoran-kotoran yang berada pada permukaan air dalam tangki uap drum. Surface blowdown dapat dilakukan tanpa mengganggu operasional dari ketel uap itu sendiri.

Bottom Blowdown dilakukan dengan maksud untuk menjaga tingkat maximum dari padatan terlarut dan terendap pada tingkat yang diizinkan. Pembuangan air dilakukan dari water drum pada ketel uap ke laut. Proses ini juga bertujuan untuk membuang endapan-endapan yang berbeda di dasar tangki water drum. Pada saat melakukan hal ini akan banyak air ketel yang terbuang ke laut yang menyebabkan jumlah air di dalam sistem berada di bawah normal, bahkan bisa medekati low water level indicator. Perlu dilakukannya pengisian kembali air ketel yang diambil dari distilatte water tank. Kandungan air ketel akan berubah karena adanya penambahan baru pada air ketel, maka dari itu perlu dilakukannya penambahan bahan kimia.

c. Filtrasi atau Penyaringan

Butiran-butiran endapan yang ada pada air ketel dapat disaring menggunakan media penyaring. Pengolahan dengan cara ini dilakukan dengan cara penyaringan pada saat air ketel mengalir dari sisi oil inspection menuju sisi suction (tanki sekunder) dari tanki air umpan. Efisiensi saringan paling baik bila unit beroperasi pada kecepatan aliran terkecil, padatan akan melalui media membawa padatan bersamanya.

Dari permasalahan yang penulis angkat terjadinya korosi sehingga terbentuk lubang dan terbentuknya deposit dalam air umpan ketel uap merusak komponen ketel penulis memilih pemecahan masalah yang dianggap paling baik dari segi proses pengetesan, pencegahan dan perawatannya.

1. Korosi pada pipa air ketel

Untuk rendahnya nilai $\mathrm{pH}$ pada air ketel langkah yang diambil adalah menambahkan chemical treatment yang sesuai dengan table ketentuan dosis secara langsung, dalam hal ini perlu dilakukan analisa air ketel melalui percobaan kimia yang benar dan akurat sesuai dengan buku instruksi manual. Hasil dari analisa kandungan kimia akan memberikan arahan mengenai dosis bahan kimia yang harus ditambahkan ke dalam sistem ketel uap. Analisa air ketel yang baik memberikan informasi yang 
tepat untuk pemberian dosis bahan kimia. Untuk meningkatkan nilai $\mathrm{pH}$ air ketel maka kita perlu menambah dosis chemical treatment sebesar $25 \%$ dan melakukan dites kembali untuk mengecek nilai $\mathrm{pH}$. Jika nilai $\mathrm{pH}$ belum mencapai ketentuan yang sesuai maka perlu ditambahkan lalu dites kembali sampai mencapai nilai yang diinginkan. Dalam pelaksanaannya diperlukan perhatian khusus pada kemampuan dan pengetahuan dari masinis yang bertanggung jawab terhadap pengaturan kualitas kandungan kimia air ketel.

2. Terjadinya deposit pada air umpan boiler

Melakukan Blowdown pada ketel uap bantu secara rutin setiap minggu, pelaksanaan blowdown adalah cara paling efektif untuk mengendalikan kualitas air ketel sehingga endapan yang berada dalam system dapat dibersihkan. Hal ini berkaitan dengan prinsip dasar yang sama dengan menguras air di dalam bak yang secara otomatis memperbaharui seluruh volume air yang berada di dalam tangki. Jika dilakukan secara rutin dan penambahan bahan kimia dilakukan sesuai dengan prosedur, maka endapan pun dapat dihindari dan usia penggunaan ketel uap bantu dapat diperpanjang.

\section{KESIMPULAN}

Berdasarkan penjabaran yang telah peneliti kemukakan pada sebelumnya, dapat disimpulkan sebagai berikut:

1. Penyebab terjadinya korosi sehingga terjadi pembentukan lubang dan peretakan pipa pada air ketel adalah:

a. Rendahnya kandungan $\mathrm{pH}$ di air ketel, cara mengatasinya adalah dengan cara menambahkan chemical treatment ke cascade tank yang sesuai dengan tabel ketentuan yang ditetapkan yaitu meningkatkan dosis sebesar $25 \%$.

b. Kurangnya penambahan chemical treatment karena kesalahan analisa air ketel sehingga perlu dilakukannya penggantian interval kegiatan analisa air ketel dari tiga hari sekali menjadi dua hari sekali dimana hasil dari kegiatan tersebut akan meningkatkan keakuratan dosis yang harus ditambahkan ke sistem air ketel.

2. Penyebab terjadinya deposit pada air umpan ketel uap disebabkan oleh tingginya kadar P. Alkalinity, penanggulangan yang dipilih adalah dilakukannya blowdown secara rutin setiap minggu untuk mengendalikan kualitas air ketel sehingga endapan dapat dibersihkan dari system dan usia pemakaian ketel uap bantu dapat lebih panjang,

Perlu kita ketahui, mengikuti prosedur yang sesuai dengan buku panduan adalah kunci terpenting di dalam setiap pekerjaan khususnya pekerjaan yang memiliki resiko tinggi seperti pekerjaan di atas kapal. Oleh karena itu, pemahaman operasional dan kesadaran akan pentingnya keselamatan bekerja sesuai buku panduan dari setiap anggota kamar mesin di atas kapal harus dilaksanakan dengan benar.

Adapun saran - saran yang dapat menjadi bahan pertimbangan bagi pembaca untuk ke depannya, yaitu:

1. Sebaiknya dilakukan sosialisasi rutin mengenai dosis bahan kimia pada ketel uap bantu, terutama bagi awak kapal kamar mesin yang baru bergabung di atas kapal

2. Dalam setiap melakukan analisa kimiawi air ketel agar dilakukan sesuai dengan buku instruksi manual.

3. Diharapkan membandingkan hasil analisa dengan laporan sebelumnya yang menjadi acuan percobaan selanjutnya.

4. Dianjurkan agar saling mengingatkan antar sesama anggota kamar mesin ketika melakukan dosis bahan kimia agar pengawasan dalam pelaksanaannya dapat berjalan secara maksimal.

\section{DAFTAR PUSTAKA}

[1] Djokosetyardjo, IR.M.J, Ketel Uap, Cetakan Pertama, Jakarta: PT. Pradnya Paramita, 1987.

[2] Djokosetyardjo, IR.M.J, Ketel Uap, Cetakan Keempat, Jakarta: PT. Pradnya Paramita, 1999.

[3] Djokosetyardjo, IR.M.J, Ketel Uap, Cetakan Kelima, Jakarta: PT. Pradnya Paramita, 2003.

[4] Djokosetyardjo, IR.M.J, Ketel Uap, Cetakan Keenam, Jakarta: PT. Pradnya Paramita, 2006.

[5] Mulianti, 2008, Pengendalian Korosi Pada Ketel Uap, Tersedia: http://id. portalgaruda.org/index.php?ref=browse $\&$ mo $\mathrm{d}=$ viewarticle\&article $=57990 . \quad$ Diakses 5 April 2018.

[6] Sulaiman, 2007, Pencegahan Korosi Dengan Boiler Water Treatment Pada Ketel Uap, Tersedia:

http://id.portalgaruda.org/index.php?ref=bro wse $\& \bmod =v i$ ew article $\&$ article $=21297$. Diakses 5 April 2018.

[7] Onny, 2016, Korosi Pada Boiler, Tersedia: http://artikel-teknoligi.com/korosi-padaboiler/. Diakses 10 Januari 2017

[8] Veen, T Van Deer, Teknik Ketel Uap, Diterjemahkan oleh Prof. Dr. Mr. Sutan Takdir Alisjahbana. Jakarta: PT. Triakso Madra, 1977. 
http://ejournal.stipjakarta.ac.id/index.php/pcsa 